\title{
Synthesis, characterization and thermochemistry of piperazine complexes of bivalent metal bromides
}

\author{
Pedro Oliver Dunstan * and Abdul Majeed Khan \\ Instituto de Quimica, Universidade Estadual de Campinas, C. P. 6154, 13084-971, Campinas, Sao Paulo, Brazil \\ ${ }^{*}$ Corresponding author at: Instituto de Quimica, Universidade Estadual de Campinas, C. P. 6154, 13084-971, Campinas, Sao Paulo, Brazil. \\ Tel.: +55.019.35213023; fax: +55.019.35213088. E-mail address: dunstan@iqm.unicamp.br (P.O. Dunstan).
}

\begin{tabular}{l} 
ARTICLE INFORMATION \\
\hline Received: 03 April 2013 \\
Received in revised form: 27 May 2013 \\
Accepted: 03 June 2013 \\
Online: 30 September 2013 \\
KEYWORDS \\
Adducts \\
Metal bromides \\
Transition metals \\
Coordinated bonds \\
Enthalpies of solution \\
Thermochemical parameters
\end{tabular}

\section{ABSTRACT}

Complexes of bivalent metal bromides with piperazine were prepared in hot ethanol solution. They have the general formula: $\left[\mathrm{MBr}_{2}(\mathrm{pipz})_{\mathrm{n}}\right]$, where $\mathrm{M}=\mathrm{Mn}(\mathrm{II}), \mathrm{Fe}(\mathrm{II}), \mathrm{Co}(\mathrm{II}), \mathrm{Ni}(\mathrm{II}), \mathrm{Cu}(\mathrm{II})$ or $\mathrm{Zn}(\mathrm{II}) ;$ pipz = piperazine; $\mathrm{n}=1$ or 1.5 . They were characterized by melting point measurements, elemental analysis, TG/DTG-DSC curves, IR and electronic spectroscopy. The enthalpies of solution of the complexes, salts and ligand were measured by thermo-chemical cycles and several thermochemical parameters were determined. The mean standard enthalpies of the metal-nitrogen coordinated bonds and the enthalpies of gaseous complex formation were also determined.

\section{Introduction}

Piperazine $N$-methyl and $N, N$-dimethyl piperazine are commonly used as ligands. They are able to coordinate with one or two metallic centers [1-4]. The energies of the metalnitrogen coordinated bonds formed by this ligand with the first row transition metals salts is yet not reported in the literature [5-12].

In this article, the interaction between transition metal(II) bromides with the ligand piperazine is studied. The energy involved in the formation of the metal(II) ion-nitrogen atom coordinated bond is determined. The values of several thermochemical parameters of the complexes have been evaluated. This can be used to interpret the coordinate bonds formed and applications in catalysis and in the chromatographic separation of the metal ions.

\section{Experimental}

\subsection{Materials}

Piperazine (99\%, Aldrich) was purified by recrystallization from methanol (M.p.: 107-108 ${ }^{\circ} \mathrm{C}$ ). Metal(II) bromides used in this work were of reagent grade. Solvents used in the synthesis of complexes were purified by distillation and stored over Linde $4 \AA$ Å molecular sieves.

\subsection{Methods}

The complexes were obtained from the interaction of metal(II) bromides and piperazine in hot ethanol solution with a molar ratio salt:ligand of 1:4. A typical procedure is as follows: to a solution of $(1.0-1.1 \mathrm{~g})\left(5 \times 10^{-3} \mathrm{~mol}\right)$ of $\mathrm{MBr}_{2}$ in 20 $\mathrm{mL}$ of hot ethanol, $(1.72 \mathrm{~g})\left(20 \times 10^{-3} \mathrm{~mol}\right)$ of piperazine dissolved in $20 \mathrm{~mL}$ of hot ethanol was added slowly and dropwise with stirring. The solid formed was filtered and washed with three portions of $20 \mathrm{~mL}$ of petroleum ether. The solid was dried for several hours in a vacuum and stored in a desiccator over calcium chloride. The analysis of $\mathrm{C}, \mathrm{H}, \mathrm{N}, \mathrm{Br}$ and metal contents confirmed the proposed stoichiometry. Carbon, hydrogen and nitrogen contents were determine by microanalytical procedures [13]. Bromine content was got by gravimetry using standard $0.1 \mathrm{M} \mathrm{AgNO}_{3}$ solution [14]. Metal content was determined by complexometric titration with 0.01 M ethylenediaminetetraacetic acid solution [15].

\subsection{Instrumentation}

A Perkin Elmer 1600 series Fourier Transformer IR Spectrophotometer was used for obtaining the IR spectra of the compounds. Samples of them in a $\mathrm{KBr}$ matrix in the region (4000 to $400 \mathrm{~cm}^{-1}$ ) were used. Spectra in the region (350-2000 $\mathrm{nm})$ were got by using a UV-Vis-NIR Varian-Cary 5G spectrophotometer. A standard reflectance attachment for obtaining the spectra of the solid compounds was used.

\subsection{Thermal studies}

Thermogravimetric (TG/DTG) and differential scanning calorimetry (DSC) measurements were got in an argon atmosphere by using a Du Pont 951 analyzer with samples with masses from (6.68 to $11.84 \mathrm{mg}$ ) (TG/DTG) and from (2.70 to $5.42 \mathrm{mg}$ ) (DSC). The heating rate was of $10 \mathrm{~K} / \mathrm{min}$ in the range temperature of (298 to $678 \mathrm{~K}$ ) (DSC) and (298 to $1248 \mathrm{~K}$ ) for (TG/DTG).

\subsection{Calorimetric measurements}

The solution calorimetric measurements were performed in a LKB 8700-1 precision calorimeter. 
Table 1. Melting points, yields, appearance and analytical data of the compounds.

\begin{tabular}{|c|c|c|c|c|c|c|c|c|c|c|c|c|c|}
\hline \multirow[t]{2}{*}{ Complex } & \multirow[t]{2}{*}{ Yield, \% } & \multirow[t]{2}{*}{ M.p., ${ }^{\circ} \mathrm{C}$ a } & \multirow[t]{2}{*}{ Color b } & \multicolumn{2}{|l|}{$\% \mathrm{C}$} & \multicolumn{2}{|l|}{$\% \mathrm{H}$} & \multicolumn{2}{|l|}{$\% \mathrm{~N}$} & \multicolumn{2}{|l|}{$\% \mathrm{Br}$} & \multicolumn{2}{|l|}{$\% \mathbf{M}$} \\
\hline & & & & Calcd. & Obs. & Calcd. & Obs. & Calcd. & Obs. & Calcd. & Obs. & Calcd. & Obs. \\
\hline$\left[\mathrm{MBr}_{2}\right.$ (pipz) $\left.{ }_{1.5}\right]$ & 77 & $169-171$ & L. br. pw. & 20.97 & 21.25 & 3.39 & 4.69 & 12.21 & 12.29 & 46.46 & 46.23 & 15.97 & 15.75 \\
\hline$\left[\mathrm{FeBr}_{2}(\mathrm{pipz})_{1.5}\right]$ & 79 & $182-185$ & Br. pw. & 20.90 & 20.91 & 4.38 & 4.54 & 12.18 & 11.91 & 46.34 & 46.55 & 16.19 & 15.95 \\
\hline$\left[\mathrm{CoBr}_{2}(\mathrm{pipz})\right]$ & 84 & $335-337$ & Bl. pw. & 15.76 & 15.52 & 3.31 & 3.88 & 9.19 & 9.38 & 52.42 & 51.39 & 19.32 & 19.03 \\
\hline$\left[\mathrm{NiBr}_{2}(\mathrm{pipz})_{1.5}\right]$ & 31 & $178-180$ & Gr. pw. & 20.72 & 20.68 & 4.35 & 4.65 & 12.08 & 11.80 & 45.96 & 45.67 & 16.88 & 16.60 \\
\hline [CuBr $2($ pipz)] & 94 & $128-130$ & Gr. pw. & 15.52 & 15.39 & 3.26 & 3.25 & 9.05 & 8.78 & 51.64 & 51.54 & 20.53 & 20.12 \\
\hline$\left[\mathrm{ZnBr}_{2}(\mathrm{pipz})\right]$ & 89 & $330-332$ & Wh. pw. & 15.43 & 16.20 & 3.23 & 2.96 & 9.00 & 9.10 & 51.33 & 51.28 & 21.00 & 21.08 \\
\hline
\end{tabular}

a Melting point with decomposition.

b Key: Br., brown; Bl., blue; Gr., green; Wh., white; L., light.

Table 2. Main infrared spectral data for pipz and its complexes a.

\begin{tabular}{|c|c|c|c|c|c|c|c|}
\hline Pipz b & {$\left[\mathrm{MnBr}_{2}\right.$ (pipz) 1.5$]$} & {$\left[\mathrm{FeBr}_{2}(\text { pipz })_{1.5}\right]$} & {$\left[\mathrm{CoBr}_{2}\right.$ (pipz)] } & {$\left[\mathrm{NiBr}_{2}\right.$ (pipz) $\left.{ }_{1.5}\right]$} & {$\left[\mathrm{CuBr}_{2}\right.$ (pipz)] } & {$\left[\mathrm{ZnBr}_{2}\right.$ (pipz)] } & Attribution \\
\hline $3328 \mathrm{~m}$ & $3172 \mathrm{~m}$ & $3173 \mathrm{~m}$ & $3247 \mathrm{~m}$ & $3173 s$ & $3174 \mathrm{~s}$ & $3199 \mathrm{~s}$ & $v_{\mathrm{NH}}$ \\
\hline $1425 \mathrm{~s}$ & $1455 \mathrm{~m}$ & $1435 \mathrm{~m}$ & $1440 \mathrm{~m}$ & $1455 \mathrm{~m}$ & $1445 \mathrm{~m}$ & $1439 \mathrm{~m}$ & $v_{\mathrm{CC}}$ \\
\hline $860 \mathrm{~m}, 816 \mathrm{~m}$ & $873 \mathrm{~m}, 817 \mathrm{~m}$ & $873 \mathrm{~m}, 817 \mathrm{~m}$ & $871 \mathrm{~m}$ & $873 \mathrm{~m}, 818 \mathrm{~m}$ & $883 \mathrm{~s}, 810 \mathrm{~m}$ & $870 \mathrm{~s}, 807 \mathrm{~m}$ & $\delta_{\mathrm{HNC}}$ \\
\hline
\end{tabular}

a Intensity of bands: $\mathrm{m}$, medium; s, strong.

${ }^{\mathrm{b}} \mathrm{In} \mathrm{CCl}_{4}$.

The measurements were performed at $(298.15 \pm 0.02 \mathrm{~K})$ by using thin walled ampoules containing reactant. These were broken in a $(100 \mathrm{~mL})$ glass reaction vessel containing (100.00 $\mathrm{mL}$ ) of calorimetric solvent [16]. The accuracy of the equipment was determine by dissolving tris(hydroxylmethylamino) methane in $0.1 \mathrm{~mol} / \mathrm{dm}^{3}$ hydrochloric acid. The result $(-29.78 \pm 0.03 \mathrm{~kJ} / \mathrm{mol})$ is in agreement with the value recommended by IUPAC $(-29.763 \pm 0.003 \mathrm{~kJ} / \mathrm{mol})$ [17]. The uncertainty intervals are twice the standard deviations of the means of about three to six replicate measurements on each compound.

\section{Results and discussion}

The interaction of $\mathrm{MBr}_{2}$ and piperazine leads to compounds of definite stoichiometry. The yield, capillary melting points, colors, appearance, and analytical data are reported in Table 1. The 1.5 coordination number is typical of polymeric complexes in which $\left[\mathrm{MBr}_{5} \mathrm{~L}\right]^{3-}$ units are linking to units $\left[\mathrm{MBr}_{4} \mathrm{~L}_{2}\right]^{2-}$ by means of bridging bromide ions or dimeric structures in which a bidentated ligand is shared between two metallic centers.

\subsection{Infrared spectra}

Table 2 presents the more important IR bands of the compounds. The pattern of the IR spectra of the complexes is similar to that of the free peperazine, although dislocation and splitting of some bands is observed. Considerable shifts to lower frequencies of the stretching vibration of $\mathrm{NH}$ group $\left(\mathrm{v}_{\mathrm{NH}}\right)$ of coordinated piperazine are observed. This shows that the ligand is coordinated to the metal ion by means of the nitrogen atom of the $\mathrm{NH}$ group [18-21].

\subsection{Thermal studies}

The thermogravimetry of the compound of Mn(II) shows the loss of the ligand in three steps of mass loss, leaving a residue that is the manganese bromide content. The complex of $\mathrm{Fe}(\mathrm{II})$ loses the ligand in two steps of mass loss, leaving a residue that is the iron bromide content. The compound of Co(II) loses the ligand in three steps of mass loss. In the third step also loses part of the bromine content. Part of the bromine content is lost in the fourth and fifth steps of mass loss, leaving a residue that is part of the bromine content together with the metal content. The complex of $\mathrm{Ni}(\mathrm{II})$ loses the ligand in two steps of mass loss following by the loss of part of the bromine content in a third step of mass loos, leaving a residue that is part of the bromine content together with the metal content. The compound of $\mathrm{Cu}(\mathrm{II})$ loses the ligand in two steps of mass loss. Part of the bromine content is also lost in the second step; following by the loss of the rest of the bromine content in a third step of mass loss together with part of the metal content, leaving a residue that is part of the metal content. The complex of $\mathrm{Zn}(\mathrm{II})$ loses the ligand in the first step of mass loss together with part of the bromine content. The rest of the bromine content together with part of the metal content is lost in a second step of mass loss, following by the loss of part of the metal content in a third step of mass loss, leaving a residue that is part of the metal content. The DSC curves are consistent with the TG data. They present endothermic peaks due to the elimination of part of the ligand content or part of the bromine content. The $\mathrm{Cu}(\mathrm{II})$ complex presents two exothermic peaks due to the decomposition of intermediate products. Table 3 shows the thermoanalytical data of the complexes.

\subsection{Electronic spectra}

The ligand field parameters for the $\mathrm{Ni}(\mathrm{II})$ complex were calculated according to Reedijk et al. [22] and Lever [23]. The number and position of the observed bands and the magnitude of the crystal field parameters as compared with that of Bolster [24] indicates that the $\mathrm{Ni}(\mathrm{II})$ complex is pseudo-tetrahedral with each $\mathrm{Ni}(\mathrm{II})$ ion surrounded by two bromide ions and one nitrogen atom from a monodentate piperazine molecule and one nitrogen atom from a bridging piperazine bidentate molecule, in a dimeric structure (Figure 1). The Co(II) complex shows bands attributed to pseudo-tetrahedral species, with each Co(II) ion surrounded by two bromine ions and two nitrogen atoms from a bidentate ligand molecule (Figure 2). The ligand field parameters were calculated according to Lever [23]. The electronic spectra of $\mathrm{Cu}(\mathrm{II})$ complex shows a rather broad band with no distinct maximum, characteristic of pseudo-tetrahedral symmetry, with each $\mathrm{Cu}(\mathrm{II})$ ion surrounded by two bromine ions and two nitrogen atoms from a bidentate ligand molecule (Figure 2). The ligand field parameters of the complex of Fe(II) were calculated according to Bolster [24]. It is concluded that $\mathrm{Fe}(\mathrm{II})$ ion is pseudo-octahedral with units $\left[\mathrm{FeBr}_{3} \mathrm{~L}_{2}\right]^{1-}$ with one bidentate ligand and units $\left[\mathrm{FeBr}_{5} \mathrm{~L}\right]^{3-}$ in a polymeric chain of bridging bromide ions (Figure 3). The complex of Mn(II) according with the position of the absorption band [24] is pseudo-octahedral with units $\left[\mathrm{MnBr}_{3} \mathrm{~L}_{2}\right]^{3-}$ with one bidentate ligand and units $\left[\mathrm{MnBr}_{5} \mathrm{~L}\right]^{3-i n}$ a polymeric chain of bridging bromide ions (Figure 3). Table 4 contains the band maxima assignments and calculated ligand field parameters of the compounds.

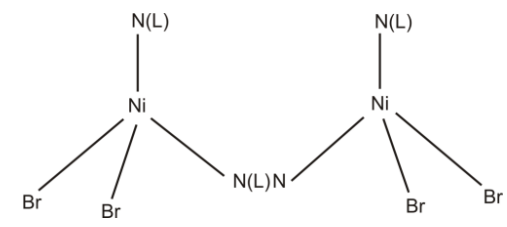

Figure 1. Structure of dimeric complex $\left[\mathrm{NiBr}_{2}(\mathrm{pipz})_{1.5}\right]$. 
Table 3. Thermal analysis of the complexes.

\begin{tabular}{|c|c|c|c|c|c|c|c|}
\hline \multirow[t]{2}{*}{ Compound } & \multirow{2}{*}{$\begin{array}{l}\text { Apparent M.p. } \\
\text { (K) }\end{array}$} & \multicolumn{2}{|c|}{ Mass loss (\%) } & \multirow{2}{*}{$\begin{array}{l}\text { TG Temp. range } \\
\text { (K) }\end{array}$} & \multirow[t]{2}{*}{ Species lost } & \multirow{2}{*}{$\begin{array}{l}\text { DSC peak temp. } \\
(\mathrm{K})\end{array}$} & \multirow{2}{*}{$\begin{array}{l}\Delta H^{\mathrm{o}} \\
(\mathrm{kJ} / \mathrm{mol})\end{array}$} \\
\hline & & Calcd & Obs. & & & & \\
\hline$\left[\mathrm{MnBr}_{2}(\text { pipz })_{1.5}\right]$ & $442-444$ & $\begin{array}{l}12.52 \\
6.26 \\
18.78\end{array}$ & $\begin{array}{l}11.83 \\
5.85 \\
18.66 \\
63.66 \text { a } \\
\end{array}$ & $\begin{array}{l}397-422 \\
422-535 \\
705-754\end{array}$ & $\begin{array}{l}-0.50 \mathrm{~L} \\
-0.25 \mathrm{~L} \\
-0.75 \mathrm{~L}\end{array}$ & $\begin{array}{l}344 \\
442 \\
514\end{array}$ & $\begin{array}{l}3.75 \\
44.61 \\
21.62\end{array}$ \\
\hline$\left[\mathrm{FeBr}_{2}\right.$ (pipz) 1.5$]$ & $455-458$ & $\begin{array}{l}18.73 \\
14.98\end{array}$ & $\begin{array}{l}18.51 \\
14.79 \\
66.70 \text { a } \\
\end{array}$ & $\begin{array}{l}374-449 \\
632-715\end{array}$ & $\begin{array}{l}-0.75 \mathrm{~L} \\
-0.60 \mathrm{~L}\end{array}$ & $\begin{array}{l}331 \\
459\end{array}$ & $\begin{array}{l}20.86 \\
29.59\end{array}$ \\
\hline$\left[\mathrm{CoBr}_{2}(\mathrm{pipz})\right]$ & $608-610$ & $\begin{array}{l}16.95 \\
7.53 \\
6.87 \\
28.82 \\
2.62\end{array}$ & $\begin{array}{l}17.51 \\
8.89 \\
7.64 \\
29.24 \\
2.23 \\
34.49 \text { a } \\
\end{array}$ & $\begin{array}{l}364-391 \\
441-467 \\
537-582 \\
8411-8934 \\
1102-1126\end{array}$ & $\begin{array}{l}-0.60 \mathrm{~L} \\
-0.25 \mathrm{~L} \\
-0.15 \mathrm{~L},-0.10 \mathrm{Br} \\
-1.10 \mathrm{Br} \\
-0.10 \mathrm{Br}\end{array}$ & $\begin{array}{l}401 \\
455\end{array}$ & $\begin{array}{l}12.88 \\
21.77\end{array}$ \\
\hline$\left[\mathrm{NiBr}_{2}(\mathrm{pipz})_{1.5}\right]$ & $451-453$ & $\begin{array}{l}24.77 \\
12.38 \\
27.57\end{array}$ & $\begin{array}{l}24.89 \\
12.64 \\
26.94 \\
35.53 \text { a } \\
\end{array}$ & $\begin{array}{l}382-416 \\
416-546 \\
755-822\end{array}$ & $\begin{array}{l}-\mathrm{L} \\
-0.50 \mathrm{~L} \\
-1.20 \mathrm{Br}\end{array}$ & $\begin{array}{l}366 \\
436 \\
465\end{array}$ & $\begin{array}{l}14.89 \\
26.58 \\
10.45\end{array}$ \\
\hline$\left[\mathrm{CuBr}_{2}\right.$ (pipz)] & $401-403$ & $\begin{array}{l}13.91 \\
22.94 \\
61.08\end{array}$ & $\begin{array}{l}13.52 \\
22.53 \\
61.11 \\
2.84 \text { a } \\
\end{array}$ & $\begin{array}{l}378-420 \\
582-659 \\
834-974\end{array}$ & $\begin{array}{l}-0.50 \mathrm{~L} \\
-0.50 \mathrm{~L},-0.35 \mathrm{Br} \\
-1.65 \mathrm{Br},-0.90 \mathrm{Cu}\end{array}$ & $\begin{array}{l}394 \\
423\end{array}$ & $\begin{array}{l}-22.55 \\
-32.33\end{array}$ \\
\hline$\overline{\left[\mathrm{ZnBr}_{2}(\mathrm{pipz})\right]}$ & $603-606$ & $\begin{array}{l}34.03 \\
57.41 \\
3.14\end{array}$ & $\begin{array}{l}33.70 \\
56.98 \\
2.65 \\
6.67 \text { a } \\
\end{array}$ & $\begin{array}{l}414-495 \\
663-721 \\
926-1042\end{array}$ & $\begin{array}{l}-\mathrm{L},-0.25 \mathrm{Br} \\
-1.75 \mathrm{Br},-0.60 \mathrm{Zn} \\
-0.15 \mathrm{Zn}\end{array}$ & $\begin{array}{l}605 \\
639\end{array}$ & $\begin{array}{l}1.68 \\
123.01\end{array}$ \\
\hline
\end{tabular}

\section{a Residue at $1248 \mathrm{~K}$.}

Table 4. Band maxima and calculated ligand field parameters for the complexes.

\begin{tabular}{|c|c|c|c|c|c|c|c|}
\hline Complex & $\begin{array}{l}\text { Band maxima } \\
\left(x 10^{3} \mathrm{~cm}^{-1}\right) \\
\text { d-d }\end{array}$ & $\begin{array}{l}\text { Band maxima } \\
\left(\times 10^{3} \mathrm{~cm}^{-1}\right) \\
\text { d-d }\end{array}$ & $\begin{array}{l}\text { Band maxima } \\
\left({\left.\mathrm{x} 10^{3} \mathrm{~cm}^{-1}\right)}\right. \\
\text { d-d }\end{array}$ & & & & $\begin{array}{l}\text { Inter ligand + charge transfer } \\
\left(x 10^{3} \mathrm{~cm}^{-1}\right)\end{array}$ \\
\hline \multirow[t]{2}{*}[\mathrm{MnBr}_{2}(\mathrm{pipz})_{1.5}]{} & & & 17.8 & & & & 27.6 \\
\hline & & & $v_{1}$ & $\operatorname{Dq}\left(\mathrm{cm}^{-1}\right)$ & & & \\
\hline $\begin{array}{l}\left.\mathrm{FeBr}_{2}(\text { pipz })_{1.5}\right] \\
{\left[\mathrm{CuBr}_{2} \text { (pipz)] }\right.}\end{array}$ & & & $\begin{array}{l}11.30 \\
11.3-14.0\end{array}$ & 1130 & & & $\begin{array}{l}26.6 \\
25.0\end{array}$ \\
\hline & $v_{2}$ & $v_{3}$ & Dq & B & Dq/B & $\beta\left(B / B_{0}\right)[24]$ & \\
\hline$\left[\mathrm{CoBr}_{2}\right.$ (pipz)] & 8.20 & 16.30 & 284 & 1065 & 0.267 & 1.097 & 18.8 \\
\hline$\left[\mathrm{NiBr}_{2}(\mathrm{pipz})_{1.5}\right]$ & 8.20 & 14.79 & 504 & 901 & 0.559 & 0.875 & $26.0,30.3$ \\
\hline
\end{tabular}

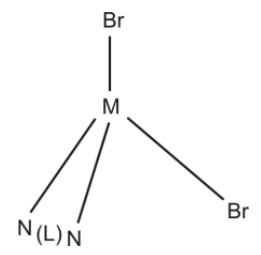

Figure 2. Structure of complex $\left[\mathrm{MBr}_{2}(\mathrm{pipz})\right]$, where $\mathrm{M}=\mathrm{Co}$ or $\mathrm{Cu}$.

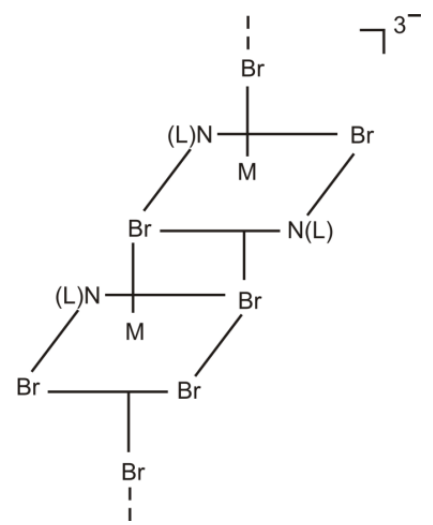

Figure 3. Structure of the complex [MBr $\left.2(\mathrm{pipz})_{1.5}\right]$, where $\mathrm{M}=\mathrm{Mn}$ or Fe.

\subsection{Calorimetric measurements}

The standard enthalpies of dissolution of metal(II) bromides, piperazine and complexes were measured [25]. It was obtained the standard enthalpies of the following reactions:

$\mathrm{MBr}_{2(\mathrm{~s})}+$ calorimetric solvent $\rightarrow$ solution A; $\Delta_{1} H^{\mathrm{o}}$

n pipz $(s)+$ solution $A \rightarrow$ solution $B ; \Delta_{2} H^{\circ}$

$\left[\mathrm{MBr}_{2}(\operatorname{pipz})_{\mathrm{n}}\right]_{(\mathrm{s})}+$ calorimetric solvent $\rightarrow$ solution C; $\Delta_{3} H^{\circ}$

solution B $\rightarrow$ solution $\mathrm{C} ; \Delta_{4} H^{\circ}$

The application of the Hess' law to reactions 1 to 4 gives the standard enthalpies of reaction acid/base $\left(\Delta_{\mathrm{r}} H^{\circ}\right)$ :

$\mathrm{MBr}_{2(\mathrm{~s})}+\mathrm{n} \mathrm{pipz(s)} \rightarrow\left[\mathrm{MBr}_{2}(\mathrm{pipz})_{\mathrm{n}}\right]_{(\mathrm{s})} ; \Delta_{\mathrm{r}} H^{\mathrm{o}}$

being $\Delta_{\mathrm{r}} H^{\mathrm{o}}=\Delta_{1} H^{\mathrm{o}}+\Delta_{2} H^{\circ}-\Delta_{3} H^{\mathrm{o}}$, because $\Delta_{4} H^{\mathrm{o}}=0$ for the dissolution of solution $\mathrm{B}$ into the solution $\mathrm{C}$. Table 5 presents the values observed for the enthalpies of dissolution of $\mathrm{MBr}_{2}$ $\left(\Delta_{1} H^{\circ}\right)$, for the enthalpies of dissolution of pipz into the solution of $\operatorname{MBr}_{2}\left(\Delta_{2} H^{\circ}\right)$ and that of the complexes $\left(\Delta_{3} H^{\circ}\right)$. Uncertainty intervals given in this table are twice the standard deviation of the means of three to six replicate measurements. Using the standard enthalpies of reaction $\left(\Delta_{\mathrm{r}} H^{\circ}\right)$ and appropriate thermochemical cycles, the thermochemical parameters were got.

The standard enthalpies of formation $\left(\Delta_{\mathrm{f}} H^{\circ}\right)$ was obtained from the equation (5):

$\Delta_{\mathrm{f}} H^{\circ}\left(\operatorname{complex}_{(\mathrm{s})}\right)=\Delta_{\mathrm{r}} H^{\mathrm{o}}-\Delta_{\mathrm{f}} H^{\mathrm{o}}\left(\mathrm{MBr}_{2(\mathrm{~s})}\right)-\mathrm{n} \Delta_{\mathrm{f}} H^{\circ}(\operatorname{pipz}(\mathrm{s}))$

The standard enthalpies of decomposition $\left(\Delta_{\mathrm{D}} H^{\circ}\right)$ were got from the equation (7): 
Table 5. Enthalpies of dissolution at $298.15 \mathrm{~K}$.

\begin{tabular}{|c|c|c|c|c|}
\hline Compound & Calorimetric solvent & Number of experiment & i & $\Delta_{\mathrm{i}} H^{\circ}(\mathrm{kJ} / \mathrm{mol})$ \\
\hline $\mathrm{MnBr}_{2(\mathrm{~s})}$ & $1.2 \mathrm{M} \mathrm{HCl}$ & 4 & 1 & $-29.46 \pm 0.43$ \\
\hline $\operatorname{Pipz}_{(\mathrm{s})}$ & 1.5:1 $\mathrm{MnBr}_{2}-1.2 \mathrm{M} \mathrm{HCl}$ & 3 & 2 & $-115.86 \pm 4.51$ \\
\hline$\left[\mathrm{MnBr}_{2}(\mathrm{pipz})_{1.5}\right]_{(\mathrm{s})}$ & $1.2 \mathrm{M} \mathrm{HCl}$ & 3 & 3 & $-45.90 \pm 0.34$ \\
\hline $\mathrm{FeBr}_{2(\mathrm{~s})}$ & $1.2 \mathrm{M} \mathrm{HCl}$ & 4 & 1 & $-70.81 \pm 1.34$ \\
\hline Pipz(s) & 1.5:1 $\mathrm{FeBr}_{2}-1.2 \mathrm{M} \mathrm{HCl}$ & 3 & 2 & $-123.77 \pm 4.15$ \\
\hline$\left[\mathrm{FeBr}_{2}(\mathrm{pipz}){ }_{1.5}\right]_{(\mathrm{s})}$ & $1.2 \mathrm{M} \mathrm{HCl}$ & 3 & 3 & $-81.10 \pm 0.73$ \\
\hline $\mathrm{CoBr}_{2(\mathrm{~s})}$ & $1.2 \mathrm{M} \mathrm{HCl}$ & 3 & 1 & $-66.91 \pm 0.46$ \\
\hline $\operatorname{Pipz}_{(\mathrm{s})}$ & 1:1 $\mathrm{CoBr}_{2}-1.2 \mathrm{M} \mathrm{HCl}$ & 3 & 2 & $-98.36 \pm 0.85$ \\
\hline$\left[\mathrm{CoBr}_{2}(\text { pipz })\right]_{(\mathrm{s})}$ & $1.2 \mathrm{M} \mathrm{HCl}$ & 3 & 3 & $-80.58 \pm 0.66$ \\
\hline $\mathrm{NiBr}_{2(\mathrm{~s})}$ & $1.2 \mathrm{M} \mathrm{HCl}$ & 4 & 1 & $-72.50 \pm 0.69$ \\
\hline $\operatorname{Pipz}_{(s)}$ & 1.5:1 $\mathrm{NiBr}_{2}-1.2 \mathrm{M} \mathrm{HCl}$ & 4 & 2 & $-108.17 \pm 2.45$ \\
\hline$\left[\mathrm{NiBr}_{2}(\mathrm{pipz})_{1.5}\right]_{(\mathrm{s})}$ & $1.2 \mathrm{M} \mathrm{HCl}$ & 4 & 3 & $-113.55 \pm 2.45$ \\
\hline $\mathrm{CuBr}_{2(\mathrm{~s})}$ & $1.2 \mathrm{M} \mathrm{HCl}$ & 3 & 1 & $-22.87 \pm 1.87$ \\
\hline $\operatorname{Pipz}_{(s)}$ & 1:1 $\mathrm{CuBr}_{2}-1.2 \mathrm{M} \mathrm{HCl}$ & 6 & 2 & $-88.15 \pm 1.68$ \\
\hline$\left[\mathrm{CuBr}_{2}(\text { pipz) }]_{(\mathrm{s})}\right.$ & $1.2 \mathrm{M} \mathrm{HCl}$ & 4 & 3 & $-14.88 \pm 1.00$ \\
\hline $\mathrm{ZnBr}_{2(\mathrm{~s})}$ & $1.2 \mathrm{M} \mathrm{HCl}$ & 4 & 1 & $-39.85 \pm 1.46$ \\
\hline $\mathrm{Pipz}_{(\mathrm{s})}$ & 1:1 $\mathrm{ZnBr}_{2}-1.2 \mathrm{M} \mathrm{HCl}$ & 5 & 2 & $-84.08 \pm 2.57$ \\
\hline$\left[\mathrm{ZnBr}_{2}(\mathrm{pipz})\right]_{(\mathrm{s})}$ & $1.2 \mathrm{M} \mathrm{HCl}$ & 5 & 3 & $-34.65 \pm 0.50$ \\
\hline
\end{tabular}

Table 6. Summary of the thermochemical results $(\mathrm{kJ} / \mathrm{mol})$ for the compounds.

\begin{tabular}{|c|c|c|c|c|c|c|c|}
\hline Compound & $\Delta_{\mathrm{r}} H^{0}$ & $\Delta_{\mathrm{f}} H^{\mathrm{o}}$ & $\Delta_{\mathrm{s}} \mathrm{g} H^{\mathrm{o}}$ & $\Delta_{\mathrm{M}} H^{\mathrm{o}}$ & $\Delta_{\mathrm{D}} H^{\mathrm{o}}$ & $\Delta_{\mathrm{r}} H^{\circ}(\mathrm{g})$ & $D_{(\mathrm{M}-\mathrm{N})}$ \\
\hline $\mathrm{MnBr}_{2(\mathrm{~s})}$ & & $-384.9 a$ & 205.9 a & & & & \\
\hline $\mathrm{FeBr}_{2(\mathrm{~s})}$ & & -249.8 a & 204 a & & & & \\
\hline $\mathrm{CoBr}_{2(\mathrm{~s})}$ & & -220.9 a & $183^{a}$ & & & & \\
\hline $\mathrm{NiBr}_{2(\mathrm{~s})}$ & & -212.1 a & 170 a & & & & \\
\hline $\mathrm{CuBr}_{2(\mathrm{~s})}$ & & -141.8 a & $182.4^{\text {a }}$ & & & & \\
\hline $\mathrm{ZnBr}_{2(\mathrm{~s})}$ & & $-328.65^{a}$ & 159.7 a & & & & \\
\hline $\mathrm{Pipz}_{(\mathrm{s})}$ & & $-45.6 \pm 1.6 b$ & $84.2 \pm 1.0 \mathrm{~b}$ & & & & \\
\hline$\left[\mathrm{MnBr}_{2}(\mathrm{pipz})_{1.5}\right]_{(\mathrm{s})}$ & $-99.42 \pm 4.54$ & $-552.7 \pm 5.1$ & $145.0 \pm 15.5$ & $-431.6 \pm 4.6$ & $225.7 \pm 4.8$ & $-286.57 \pm 16.2$ & $191.0 \pm 10.8$ \\
\hline$\left[\mathrm{FeBr}_{2}(\mathrm{pipz})_{1.5}\right]_{(\mathrm{s})}$ & $-113.48 \pm 4.42$ & $-431.7 \pm 5.0$ & $144.1 \pm 15.4$ & $-443.8 \pm 4.7$ & $239.8 \pm 4.7$ & $-299.7 \pm 14.9$ & $199.8 \pm 9.9$ \\
\hline$\left[\mathrm{CoBr}_{2}(\text { pipz) }]_{(\mathrm{s})}\right.$ & $-84.69 \pm 1.17$ & $-351.2 \pm 2.0$ & $133.6 \pm 14.3$ & $-351.9 \pm 1.5$ & $168.9 \pm 1.5$ & $-218.3 \pm 13.4$ & $109.2 \pm 6.7$ \\
\hline$\left[\mathrm{NiBr}_{2}(\mathrm{pipz})_{1.5}\right]_{(\mathrm{s})}$ & $-67.12 \pm 3.53$ & $-347.62 \pm 4.27$ & $127.1 \pm 12.7$ & $-363.42 \pm 3.83$ & $193.42 \pm 3.67$ & $-236.32 \pm 14.18$ & $118.16 \pm 7.09$ \\
\hline$\left[\mathrm{CuBr}_{2}(\text { pipz) }]_{(\mathrm{s})}\right.$ & $-96.14 \pm 2.14$ & $-283.5 \pm 3.1$ & $133.3 \pm 14.3$ & $-362.3 \pm 2.9$ & $180.3 \pm 2.9$ & $-229.4 \pm 13.6$ & $114.7 \pm 6.8$ \\
\hline$\left[\mathrm{ZnBr}_{2}(\mathrm{pipz})\right]_{(\mathrm{s})}$ & $-89.28 \pm 3.00$ & $-463.5 \pm 3.4$ & $121.9 \pm 13.2$ & $-333.2 \pm 3.2$ & $173.5 \pm 3.2$ & $-211.2 \pm 12.6$ & $105.6 \pm 6.3$ \\
\hline
\end{tabular}

bRef. [27]

Table 7. Auxiliary data and enthalpy changes of the ionic complex formation process in the gaseous phase $(\mathrm{kJ} / \mathrm{mol})$.

\begin{tabular}{|c|c|c|c|}
\hline Compound & $\Delta_{\mathrm{f}} H^{\mathbf{o}}$ & $\Delta_{\mathrm{r}} H^{\circ}(\mathrm{g})$ & $\Delta_{\mathrm{fl}} H^{\circ}$ \\
\hline $\mathrm{Br}^{-}(\mathrm{g})$ & $-219.07 \mathrm{a}$ & & \\
\hline $\mathrm{Mn}^{2+}(\mathrm{g})$ & $2522.0 \pm 0.1^{b}$ & & \\
\hline $\mathrm{Fe}^{2+}(\mathrm{g})$ & $2751.6 \pm 2.3^{b}$ & & \\
\hline $\mathrm{Co}^{2+}(\mathrm{g})$ & $2841.7 \pm 3.4 b$ & & \\
\hline $\mathrm{Ni}^{2+}(\mathrm{g})$ & $2930.5 \pm 1.5^{b}$ & & \\
\hline $\mathrm{Cu}^{2+}(\mathrm{g})$ & $3054.5 \pm 2.1^{b}$ & & \\
\hline $\mathrm{Zn}^{2+}(\mathrm{g})$ & $2781.0 \pm 0.4^{b}$ & & \\
\hline$\left[\mathrm{MnBr}_{2}(\mathrm{pipz})_{1.5}\right]_{(\mathrm{g})}$ & $-407.7 \pm 16.7$ & $-286.57 \pm 16.2$ & $-2549.4 \pm 16.4$ \\
\hline$\left[\mathrm{FeBr}_{2}(\mathrm{pipz})_{1.5}\right]_{(\mathrm{g})}$ & $-287.6 \pm 16.2$ & $-299.7 \pm 14.9$ & $-2862.9 \pm 16.4$ \\
\hline$\left[\mathrm{CoBr}_{2}(\mathrm{pipz})\right]_{(\mathrm{g})}$ & $-217.6 \pm 14.4$ & $-218.3 \pm 13.4$ & $-2659.9 \pm 14.1$ \\
\hline$\left[\mathrm{NiBr}_{2}(\mathrm{pipz})_{1.5}\right]_{(\mathrm{g})}$ & $-220.5 \pm 13.4$ & $-236.32 \pm 14.18$ & $-2770.68 \pm 14.87$ \\
\hline$\left[\mathrm{CuBr}_{2}(\text { pipz })\right]_{(\mathrm{g})}$ & $-150.2 \pm 13.9$ & $-229.4 \pm 13.6$ & $-2805.2 \pm 15.0$ \\
\hline$\left[\mathrm{ZnBr}_{2}(\text { pipz })\right]_{(\mathrm{g})}$ & $-341.6 \pm 12.8$ & $-211.2 \pm 12.6$ & $-2769.0 \pm 13.9$ \\
\hline
\end{tabular}

$\mathrm{ZnBr}_{2}(\mathrm{pipz})$

b Ref. [29].

$\left[\mathrm{MBr}_{2}(\mathrm{pipz})_{\mathrm{n}}\right]_{(\mathrm{s})} \rightarrow \mathrm{MBr}_{2(\mathrm{~s})}+\mathrm{n} \operatorname{pipz}_{(\mathrm{s})} ; \Delta_{\mathrm{D}} H^{\mathrm{o}}$

being $\quad \Delta_{\mathrm{D}} H^{\mathrm{o}}=\Delta_{\mathrm{r}} H^{\mathrm{o}}+\mathrm{n} \Delta_{\mathrm{s}}^{\mathrm{g}} H^{\mathrm{o}}($ pipz $)$.

The standard lattice enthalpy $\left(\Delta_{\mathrm{M}} H^{\circ}\right)$ was obtained from equation (8):

$\mathrm{MBr}_{2(\mathrm{~s})}+\mathrm{n} \mathrm{pipz}(\mathrm{g}) \rightarrow\left[\mathrm{MBr}_{2}(\mathrm{pipz})_{\mathrm{n}}\right]_{(\mathrm{s})} ; \Delta_{\mathrm{M}} H^{\mathrm{o}}$

being $\Delta_{\mathrm{M}} H^{\mathrm{o}}=-\Delta_{\mathrm{D}} H^{\circ}-\Delta_{\mathrm{s}} \mathrm{g} H^{\circ}\left(\mathrm{MBr}_{2}\right)$.

The enthalpy of reaction acid/base in the gaseous phase was got from equation (9):

$\mathrm{MBr}_{2(\mathrm{~g})}+\mathrm{n} \operatorname{pipz}_{(\mathrm{g})} \rightarrow\left[\mathrm{MBr}_{2}(\mathrm{pipz})_{\mathrm{n}}\right]_{(\mathrm{g})} ; \Delta_{\mathrm{r}} H^{\circ}(\mathrm{g})$

being

$\Delta_{\mathrm{r}} H^{\circ}(\mathrm{g})=-\Delta_{\mathrm{s}} \mathrm{g} H^{\circ}\left(\mathrm{MBr}_{2}\right)-\mathrm{n} \Delta_{\mathrm{s}} \mathrm{g} H^{\circ}(\mathrm{pipz})+\Delta_{\mathrm{r}} H^{\circ}+\Delta_{\mathrm{s}} \mathrm{g} H^{\circ}($ complex $)$
As the complexes decomposed on heating, the enthalpies of sublimation of the complexes were estimated [26]. From equation (9) it is got the standard enthalpies of the metalnitrogen bonds: $D_{(\mathrm{M}-\mathrm{N})}=-\Delta_{\mathrm{r}} H^{\circ}(\mathrm{g}) / \mathrm{n}$, where $\mathrm{n}$ is the number of coordinated atoms of the ligand. Table 6 presents the values obtained for all these enthalpies. The formation enthalpies of the complexes in the gaseous phase, according to the equation (10):

$\mathrm{M}_{(\mathrm{g})^{2+}}+2 \mathrm{Br}_{(\mathrm{g})^{-}}+\mathrm{n} \operatorname{pipz}_{(\mathrm{g})} \rightarrow\left[\mathrm{MBr}_{2}(\mathrm{pipz})_{\mathrm{n}}\right]_{(\mathrm{g})} ; \Delta_{\mathrm{fl}} H^{\circ}$

are equal to $\Delta_{\mathrm{fl}} H^{\circ}=\Delta_{\mathrm{f}} H^{\circ}($ complex $)-\Delta_{\mathrm{f}} H^{\circ}\left(\mathrm{M}_{(\mathrm{g})^{2+}}\right)-2 \Delta_{\mathrm{f}} H^{\circ}\left(\mathrm{Br}_{(\mathrm{g})}\right)$ - $\mathrm{n} \Delta_{\mathrm{f}} H^{\circ}\left(\operatorname{pipz}_{\mathrm{gg}}\right)$. Table 7 shows the values obtained for these enthalpies. The acidity order obtained based on $\Delta_{\mathrm{r}} \mathrm{H}^{\circ}$ values for the complexes of the same stoichiometry is: $\mathrm{Fe}(\mathrm{II})>\mathrm{Mn}$ (II) $>$ $\mathrm{Ni}(\mathrm{II})$ and $\mathrm{Cu}(\mathrm{II})>\mathrm{Co}(\mathrm{II})$. Using the values of $D$ the order is the same with the inversion of the positions of Co(II) and $\mathrm{Zn}(\mathrm{II})$. 


\section{Acknowledgements}

One of us (Abdul Majeed Khan) wants to acknowledge TWAS (The Academy of Sciences for the Developing World)/CNPq (Conselho Nacional de Pesquisa) organizations for a fellowship, which made it possible for him to undertake the above research at the University of Campinas.

\section{References}

[1]. Ciccarese, A.; Clemente, D. A.; Fanizzi, F. P.; Marzotto, A.; Valle, G. Acta Crystallogr. C 1998, 54, 1779-1781.

[2]. Smekal, Z.; Travnycek, Z.; Mrozimski, J.; Marek, J. Inorg. Chem. Commun. 2003, 65, 1395-1399.

[3]. Bera, M.; Ribas, J.; Wong, W. T.; Ray, D. A. Inorg. Chem. Commun. 2004, 7, 1242-1245.

[4]. Johnstone, N. C.; Aazam, E. S. Hitchcock, P. B.; Fulton, J. R. J. Organomet. Chem. 2010, 695(2), 170-176.

[5]. Marzotto, A.; Clemente, D. A.; Valle, G. Acta Crystallogr. C 1988, 54, $27-$ 29.

[6]. Khalaj, A.; Adibpour, N.; Shahverdi, A. R.; Danaeshtalab, M. Eur. J. Med. Chem. 2004, 39, 699-705.

[7]. Bali, A.; Sharma, K.; Bhalla, A.; Bala, S.; Reddy, D.; Singh, A.; Kumar, A. Eur. J. Med. Chem. 2010, 45, 2656-2662.

[8]. Aytemir, M. D.; Calis, U.; Ozalp, M. Arch. Pharm. Res (Weinheim) 2004, 337, 281-288.

[9]. Sapa, J.; Filipek, B.; Nowinski, L. Pharmacol Rep. 2011, 63, 455-463.

[10]. Patel,I. J.; Parmar, S. J. E-J. Chem. 2010, 7, 617-623.

[11]. Pietrzycka, A.; Stepniewski, M.; Waskielewicz, A. M.; Marona, H. Acta Pol. Pharm. Drug Res. 2006, 63, 19-24.

[12]. Rajabalian, S.; Foroumadi, A.; Shafiee, A.; Emami, S. J. Pharm. Pharm. Sci. 2007, 10, 153-158.

[13]. Niederl, J. B.; Sozzi, J. A. Microanalisis elemental organico. $1^{\text {st }}$ edition, Buenos Aires, Methopress, 1958.

[14]. Koltoff, I. M.; Sandall, E. B. Tratado de Quimica Analitica Cuantitativa, 3a edicion, Libreria y Editorial Nigar S. R. L., Buenos Aires, 1956.

[15]. Flaschka, H. A. EDTA titrations: An Introduction to Theory and Practice, 2nd edition, Pergamon Press, London, 1964.

[16]. Dunstan, P. O. J. Chem. Eng. Data 1999, 44, 243-247.

[17]. Herington, E. F. Pure Appl. Chem. 1974, 40, 391-450.

[18]. Ahuya, I. S. Inorg. Chim. Acta 1969, 3, 110-112.

[19]. Ahuja, I. S.; Garg, A. Inorg. Nucl. Chem Lett. 1973, 7, 937-940.

[20]. Pellacani, G. C.; Battistuzzi, R.; Marcotrigiano, G. J. Inorg. Nucl. Chem. 1973, 35, 2243-2247.

[21]. Soriego, R.; Costamagna, J. A. J. Inorg. Nucl. Chem. 1971, 33, 15281532 .

[22]. Reedijk, J.; Van Leeuwem, P. W. N. M.; Groenveld, W. L. Recl. Trav. Chim. Pay-B. 1968, 87, 129-141.

[23]. Lever, A. B. P. J. Chem. Educ. 1968, 45, 711-712.

[24]. Bolster, M. W. G. The coordination chemistry of aminophosphinoxide and related compounds, Thesis, Leiden, 1972 pp. 88, 89, 95, 98, 100.

[25]. Dunstan, P. O. J. Chem. Eng. Data. 2009, 54, 842-846.

[26]. Dunstan, P. O. Thermochim. Acta 2004, 409, 19-24.

[27]. Dunstan, P. O. Thermochim. Acta 1997, 303, 209-218.

[28]. Wagmam, D. D.; Evans, W. H.; Parker, V. B.; Schumm, R. H. Halow, I.; Churney, S.; Nuttall, R. L. J. Phys. Chem. Ref. Data 1982, 2, 50-191.

[29]. Skinner, H. A.; Pilcher, G. Q. Rev. Chem. Soc. 1963, 17, 264-288. 